\title{
Ode to an invisible woman: The story of qualified adults and partners in Ireland
}

\section{Mary P Murphy}

Department of Sociology, Maynooth University, Ireland

\begin{abstract}
Ireland used the Great Recession as an opportunity to pursue controversial reforms to lone parent social security payments while ignoring a significantly larger group of Irish women, qualified adults, the partners of coupled social welfare claimants. A review of the international literature about partners and recent policy trends is used to contextualise previously unpublished qualitative data capturing the practical experience of Irish partners and recent policy trends in relation to Irish partners. Despite the significant crisis-related rise in numbers of working aged qualified adults in Ireland, we see strong policy inertia in relation to this largely invisible group. The barriers to and lack of urgency for reform can be explained by several factors including fear of political backlash, ambiguous cultural norms about women's roles, and practical capacity or lack of resources. The present policy architecture offers clear patriarchical dividends for male partners, employers and the policy elite, all of whom benefit from and remain attached to the concept of and the practice of a modified form of wifely labour. Policy avoidance cannot continue indefinitely, as reform of family-based welfare payments is central to resolving key policy problems including high participation rates and addressing child poverty. Options are briefly explored.
\end{abstract}

\section{Keywords}

Ireland, partners, qualified adults, social security reform, wifely labour

\section{Corresponding author:}

Mary P Murphy, Department of Sociology, Maynooth University, Maynooth, Co. Kildare, Ireland.

Email: mary.p.murphy@nuim.ie 


\section{Introduction}

Ireland has experienced an unprecedented rise in women's labour force participation. Current EU and Irish employment, social inclusion and gender equality strategies aim to further increase the numbers of women and mothers in work. A decade ago, an Irish government discussion paper (Department of Social and Family Affairs (DSFA), 2006) proposed reforms to tackle barriers preventing economic participation of both lone mothers and qualified adults (QAs). QAs are defined as the spouses or partners of social security claimants on whose behalf claimants are paid a Qualified Adult Allowance (QAA), QAs are hereafter referred to as partners. Anticipating policy change, a number of Irish studies focused on activation of lone parents (Civic Forum, 2015; Millar et al., 2007; Murphy, 2008, 2012; One Family, 2008). While partners numerically outstrip lone parents in Ireland, little sociological research or policy attention has focused on this group. Without filling this knowledge gap it is unlikely that Irish policy can meet instrumental gender employment goals or eradicate child poverty. At a more normative level it is hard to progress gender equality while ignoring one of the fundamental pillars of a male breadwinner gender regime (Sainsbury, 1999). This article has two primary objectives: (a) to analyse previously unpublished qualitative interviews with partners about attitudes to employment and to make visible the lives and concerns of partners; (b) to understand why, despite clear policy justification and international trends, Irish policy continues to largely ignore partners. The methodology is informed by an international literature review, analysis of qualitative interviews with 10 partners conducted near Dublin, Ireland in 2008, interviews with four statutory and civil society policy actors conducted in 2014 and analysis of policy reports and parliamentary debates. 'International literature and policy trends' (Section One) provides international context, examines relevant international literature on partners' barriers to employment and outlines policy trends in this area. 'The Social security development in Ireland' (Section Two) describes the historical trajectory of the Irish QA payment, explores policy developments since 2006 and charts the significant rise in the number of QAs during the crisis. The 'Giving voice to partners or QAs in Ireland' (Section Three) gives voice to Irish partners. 'The discussion' (Section Four) analyses partners' views on and experiences of labour market engagement. Finally 'the conclusion' (Section Five) compares and reflects on divergence in Irish policy between lone parents and partners and between Irish and international trends regarding partners, and reflects on future policy.

\section{International literature and policy trends}

Partners, as used here, refers to partners of main benefit claimants in and out of paid employment and includes individuals (male or female, with or without children) who are married to, or cohabiting with, a primary social security claimant and on whose behalf the primary claimant claims a portion of the overall social welfare entitlement. This section addresses two key issues: (a) what the literature 
tells us about the barriers and experiences of partners, and (b) international trends in policy regarding partners.

\section{International literature}

The literature on partners in family based means-tested social welfare systems is largely drawn from Anglo-Saxon states where such payments predominate (McCashin, 2004), but also from Denmark and Germany. We draw on generalisable and transferable literature so as to situate the experience of Irish partners and policy change. We focus on obstacles to paid employment that appear specific to partners - primarily issues relating to marital or couple homomany and codependence, specific care and health barriers and issues related to joint financial decision making processes (Collard and Atkinson, 2009; Schober and Scott, 2012). We briefly expand on these headings before examining international policy trends in relation to partners.

Marital and couple homogamy and codependence. Beyond general obstacles to returning to work (Russell et al., 2002), specific partner barriers relate to personal life situations where partners often share similar characteristics with respect to age, ethnicity, education and health (Singley and Callister, 2004). Such partners live codependent lives where decisions are complex and mediated through family and gendered moral rationalities (Arrowsmith, 2004; Daly and Klammer, 2005; Duncan and Irwin, 2004). In this context, the attitudes of one partner can impact on the other and barriers encountered by one likewise can affect the other (Bewley et al., 2005; Bonjour and Dorsett, 2002). Gendered roles are common in such couples. In Australia and New Zealand, female partners' lives were strongly correlated with domestic care (King et al., 1995). UK research (Stone et al., 2000) found female partners often live with unemployed males who assume breadwinner roles free of care responsibility and that this particularly applies in certain ethnic minority groups and within traditional working class areas (Aston et al., 2007; Bennett, 2002; Bewley et al., 2005).

Care and health. Caring responsibilities constitute a different type of participation barrier to paid work for partners than they do for lone parents (Arrowsmith, 2004; Carlile et al., 2002; Coleman and Seeds, 2007; Singley, 2003). Larger families militate against partnered women's re-entry, as do class differences in ideologies about motherhood and caring (Kasparova et al., 2003; McRae, 2003), with some women ambivalent of reluctant to leave children in the care of male partners. Lone parents appear more concerned about the costs and availability of childcare than respondents in workless couples (Savage et al., 2014), with both sometimes reluctant to leave children in the care of others (Arrowsmith, 2004). Partnered women on welfare-to-work programmes report a time crunch balancing employability expectations with wider care giving responsibilities (Gazso, 2007). Daly and Leonard (2002) found Irish female partners prioritise maternal roles and being present for 
children, and are not relieved of domestic duties even when the male is unemployed. Health obstacles have to be understood with reference to both the main claimant and the household as a whole, with one partner often withdrawing from work in order to provide care for the other. Those with domestic care responsibility have less autonomy and control over availability and consequently need more flexible employment. Women in non-working households report a higher incidence of health or disability problems compared to their working counterparts or lone parents (Arrowsmith, 2004; Coleman and Seeds, 2007). Older partners and partners with health problems are more likely to have negative views around work (Renda, 2007). Relationship tensions also tend to be evident. One third of all married or cohabiting women experience some form of physical abuse (Kornstein and Wojcik, 2002). Women in violent relationships are particularly vulnerable when partners exploit financial dependence and/or employ physical means to sabotage women's ability to gain independence by working (Crowley, 2015; Women's Aid, 2014).

Financial concerns and decision making. Women rate money worries higher than and experience poverty differently to men, who maintain greater access to money for personal expenditure than women who manage household and child-related expenditure (Daly and Leonard, 2002). Financial worry also contributes to health problems. Fear of losing benefits in low income couple households can far outweigh potential financial gains from employment. Employment decisions are framed in terms of their impact on total family earnings and who earns the income. Calculations are complex and it matters in internal negotiations who directly loses and who gains (Bewley et al., 2005; Coleman and Seeds, 2007; Daly and Leonard, 2002). Partners are concerned about how earnings affect the other partner's social welfare payment, and the stability and security of payments are also crucial (McCashin, 2004). Policy is not necessarily sensitive to the heterogeneity and diversity of the needs of partners, and implementation processes often fail to accommodate the complexity of financial, family care and other decisions. Case worker discretion is key; and policy is often weakly and ambiguously implemented (Kopf and Zabel, 2014). Bewley et al. (2005) found insufficient training left British job centre staff lacking in knowledge around the process of joint decision making between spouses, found gender bias in offers to partners and a lack attention to the important role of care giving relative to paid employment.

\section{Policy trends}

Gender regimes are a complex set of rules and norms that create established expectations as well as allocate rights and tasks between the sexes, effectively structuring gender relations (Sainsbury, 1999: 5). They include the institutional and cultural framework of options and constraints that shape the labour market preferences and participation of mothers (Keck and Saraceno, 2013). Policy is often ambiguous about mothers and employment, with family and labour market policy often pulling in different directions (Daly, 2011). Different jurisdictions operationalise 
differential treatment of lone parents and coupled parents and of partnered and single women (Korpi et al., 2013). Overall policy reflects shifts in attitudes and increased acceptance that both members of cohabitating couples should work and cultural shifts with men and women experiencing changing norms in relation to care giving (Schober and Scott, 2012). That said, attitudinal shifts are often prompted by the reality that adults in low income households also have to assume dual roles to meet stricter welfare conditions for financial support (McLeavy, 2007). Daly (2011) finds overall that policy encourages mothers to work outside the home with, for example, the elimination of housewife bonus by individualising taxation (except in France, Germany and Ireland).

Reviewing specific changes to policy regarding partners, Millar observed as early as 2003 that partners of those receiving social security benefits have become a target group for policy in their own right (Millar, 2003: 67). By 2011, alongside lone parents, partners in social assistance (means-tested) programmes were increasingly a target for paid work and less exempt from work obligations (Ingold and Etherington, 2013). Ingold (2010: 35) notes the challenge of accessing information about policy trends in relation to the largely invisible group 'partners', but tracks a number of policy shifts in Denmark, UK and Australia. The Danish 300 hours rule (300 timers reglen), was introduced in 2006 for married couples claiming meanstested social assistance payments, partly in response to the challenge of integrating migrant women with different cultural expectations of participating in paid employment. In the context of increased activation, a new Australian Parenting Payment (PP) required partnered women to claim in their own right, while Australians Working Together (2003) and Welfare to Work (2006) increased conditionality for partners. Ingold and Etherinton (2013) chart the trajectory of UK policy for partnered women, also introduced in the context of a work-first activation policy, with the 1999 'New Deal for Partners'. Joint claims for Jobseeker's Allowance (JSA) were introduced in 2001 to target partners of main benefit claimants without children (Arrowsmith, 2004). In 2008, JSA joint claims were extended to couples with children. Scotland piloted a voluntary approach in 'Working for Families' (McQuaid et al., 2013). Elsewhere, and again in the context of activation, the 2005 German Hartz IV reforms for partners (Leschke and Jepsen, 2014; Lietzmann, 2014), shifted policy from a strong facilitation of maternal care to making employment participation obligatory for both partners. In the German context, participation is conditional on childcare availability, and case worker discretion means policy is ambiguously implemented particularly in western Germany (Kopf and Zabel, 2014; Lietzmann, 2014).

We conclude that the literature differentiates experiences of partners from those of lone parents and proceed to test whether similar partner experiences of marital or couple homomany and codependence, specific care, health and employment barriers and issues related to joint financial decision making processes are present in the Irish context. We examine the degree to which Irish partners have become a target group for policy in their own right, and if not what might explain Ireland's continued 
reluctance to target partners (McCashin, 1997), especially given Irish developments in work-first activation, the policy context for targeting partners elsewhere.

\section{Social security development in Ireland}

Policy in Ireland has always played a role in constructing women's lives and institutionalising gender inequality within the family, welfare and labour market institutions (O'Connor and Murphy, 2008). Women were classified according to their relationship with absent breadwinners (widows, deserted wives, prisoners' wives and unmarried mothers) or regarded as mothers in a male breadwinner model which encouraged 'wifely labour' and discouraged women's full labour market participation (McCashin, 2004, 1997). The 'QA' portion of the family social welfare payment was a key mechanism in this regard. Since 1973 EU equality norms apply to Ireland and, on foot of legal campaigns, by 1984 direct discrimination was removed from the social welfare code and dependency was defined by gender neutral rules which determined who qualified as a full QA. The 'qualified' adult has to earn below a certain weekly income threshold (introduced as $£ 50$ in 1984, updated to $€ 88$ in 2001 and $€ 100$ in 2007). This formal definition of dependency applied to both means-tested assistance and insurance-based payments and now applies to all married, cohabiting, opposite and same sex couples. Regardless of whether or not there are dependent children, for a job seeker claimant, married to or cohabiting with a partner earning under the required threshold, can claim a maximum QA payment limited to approximately 70 per cent of the primary claimant's entitlement (those earning between $€ 100.01$ and $€ 310$ gross per week qualify for a tapered QA adult payment). In 2015, the full QA amounted to $€ 124.70$ or 68 per cent of the $€ 188$ primary claim, with higher amounts for contributory and non-contributory pensions and lower amounts for JSA claimants aged 18-14. This 'limitation rule' applied to job seeker households is justified on grounds of economies of scale and is consistent with a male breadwinner ideology which treats the family as one unit (Daly and Kelly, 2015). Limitation plays a role in keeping replacement ratios low and also contributes to household formation barriers for low income couples (Murphy, 2003). While both a man and woman can technically be a QA, in practice the phenomenon has been gendered, with women comprising up to 98 per cent of QAs (Murphy, 2003). In theory, access to social security is gender neutral and both partners in a non-employed coupled household can directly access a JSA. However, this requires that they know they can do so and are facilitated to do so. In reality, there are practical and administrative barriers, with female partners with care responsibilities often required to demonstrate they can provide childcare. In practice therefore, most female partners do not seek an individualised payment; rather the default position assumes women in coupled relationships have a dominant care role and are not job seekers. This means they are not subject to conditionality or sanctioned for failure to take up activation offers, but also means less access to training and employment opportunities, less ability to 
secure pension entitlement and no presence in unemployment statistics. They remain invisible.

QA earnings impact not only on the amount of QA paid but also impact on the family payment. Since 2008 both the job seeker claimant and the QA or 'partner' is each allowed to earn $€ 20$ per day before the family welfare payment is reduced by 60 cents for every euro earned. The primary claimant is restricted to three days' part-time work; however the QA has no such restriction and can work flexibly across the week. Between 40 and 60 per cent of QAs utilised these earnings disregards, suggesting a pattern of lowpaid and part-time work for many QAs (McKeon, 2015; Murphy, 2012).

In 1973, the Irish government introduced the unmarried mother's allowance, a means-tested payment for unmarried women with children. Over time this transitioned into the One-Parent Family Payment (OFP) which, until recently, supported a lone parent to care unconditionally for a child up to age 21, as long as the child was in full-time education. From the early 1990s the payment contained generous work incentives for lone parents in the form of earned income disregards. While designed to compensate for childcare costs, these disregards were allowed regardless of what childcare costs were incurred.

A comparison of mid-2000s Irish policy for lone parents and partners shows partners had less financial incentives to move into paid employment. This reflected traditional patriarchal assumptions about married women's domestic role and resistance to encouraging significant employment outside the home for partners. In contrast, policy encouraged and supported lone parents to work longer hours outside the home. Table 1 shows, in the late 1990s, a range of reports (Department of Social, Community and Family Affairs (DSCFA), 1996, 1999) reviewing reform proposals for QAs', lone parents' and women's labour market participation. These considered various policy objectives including cohabitation rules, individualisation, integration of taxation and social welfare and household economies of scale. McCashin (1997: 6) examined ways to progress individualisation and focused on replacing the QA with a Homemaker Responsibility Allowance to give income support to home based carers alongside abolition of the limitation rule so both adults in a jobless household could access the full rate of unemployment payment. Feminist groups and femocrats championing individualisation (NWCI, 2006) influenced Minister Séamus Brennan, who in 2006 proposed to eliminate the concept of QA and cohabitation and replace both with a parenting allowance (DSFA, 2006). This reform agenda, which reflected policy developments in the Australian Parenting Payment (Millar, 2003), was broadly welcomed but abruptly derailed by the crisis.

DSFA (2006) proposed to replace the current OPFP and QA with a household means-tested Parental Allowance (PA) for parents of children up to age seven, and a part-time conditional JSA for lone parents with children over seven. It proposed that the partnered parent retain the option of resort to the QA when the youngest child turned seven. In preparation, Budget 2007 introduced a change in meanstesting rules to make the QA income disregard consistent with the JSA income disregard. By early 2009 the government, abandoned plans for a 'parenting payment'. Subsequent 2010 proposals to reform primary social assistance payments 
Table I. Irish gender and social security trajectory 1973-2015.

1973

1973

1979

1984

1994

$1996-1999$

2000

2006

2007

2010

$2012-2015$
Ireland joins European Economic Community and is subject to gender equality principles

Introduction of Unmarried Mothers Allowance for lone parents with children aged up to $2 \mathrm{I}$ if in full-time education

EU Directive on Equal Treatment in Social Security

Reforms to remove unequal treatment - introduction of limitation rule, definition of dependency or 'qualified adult' as the framework for partners In Ireland

Pro-employment reforms for both lone parents and QAs means assessments

DSFCA (1996, 1999) policy processes and reports on reforms on social welfare and taxation relating to individualisation, QAs and lone parents reforms

P2000 Women's Participation in the Labour Market

DSFA 2006 Proposals to reform lone parents and QAs payment influenced by Australian reforms

QA reforms, earned disregards simplified, made consistent with JSA, employment traps eased

DSP proposals to introduce a Single Working Age Payment (rejected by parliamentary committee in context of lack of resources to invest in child care and other supports)

Significant reforms introduced to reduce income disregards and make paid employment conditional for lone parents whose youngest child is $14+$.

No parallel reforms to QAs

into a Single Working Age Payment (SWAP; Department of Social Protection, 2010) were largely abandoned when the proposals were recognised as both politically and practically unfeasible. The government left to one side any ambition to reform QA payments but maintained its focus on activating lone parents.

The momentum to reform the OPF culminated in Budget 2012, when government announced a four year reform agenda (completed in July 2015) to cease access to the OFP for lone parents whose youngest child is seven or over. Lone parents whose youngest child is between seven and 13 now access an unconditional Job Seekers Transition Allowance (JSTA). While job seekers means-testing rules apply, the lone parent on JSTA is not required to seek full-time work and more flexible part-time work patterns are accommodated. Lone parents whose youngest child is 14 or older must claim JSA and are obliged to seek and accept full-time work under the same conditions and rules as apply to single people with no children (Murphy, 2014). In contrast, in 2015 the QA is not required to seek work, entitlement to this payment is not contingent on either parenting or care responsibilities and the payment can support the 'wifely' role of a full-time traditional housewife (Shaver and Bradshaw, 1995). These contrasting experiences of lone parents and QAs are outlined in Table 2. Even with introducing conditionality for lone parents, Ireland still 
Table 2. Levels of differentiated conditionality for lone parents and partners.

\begin{tabular}{|c|c|c|c|c|}
\hline & $\begin{array}{l}\text { Lone parent } \\
\text { with child } \\
\text { under } 7\end{array}$ & $\begin{array}{l}\text { Lone parent } \\
\text { with child } 7-13\end{array}$ & $\begin{array}{l}\text { Lone parent } \\
\text { with } \\
\text { child I4+ }\end{array}$ & \multirow{2}{*}{$\begin{array}{l}\text { Primary JA } \\
\text { claimant, } \\
\text { QA and child 0-2I } \\
\text { (in full time } \\
\text { education) }\end{array}$} \\
\hline & $\begin{array}{l}\text { One parent } \\
\text { family payment }\end{array}$ & $\begin{array}{l}\text { Job seeker's } \\
\text { transitional, } \\
\text { child } 7-14\end{array}$ & $\begin{array}{l}\text { Job Seekers } \\
\text { Allowance }\end{array}$ & \\
\hline $\begin{array}{l}\text { Is woman* required to be } \\
\text { available for work? }\end{array}$ & No & No & Yes & No \\
\hline $\begin{array}{l}\text { Is woman required to } \\
\text { genuinely seek work? }\end{array}$ & No & No & Yes & No \\
\hline $\begin{array}{l}\text { Does woman have access to } \\
\text { active labour market pro- } \\
\text { grammes and supports? }\end{array}$ & No & Yes & Yes & No \\
\hline
\end{tabular}

Source: compiled by author.

*Woman is used because over 90 per cent of lone parents and qualified adults are women.

remains something of an outlier in this area, with age 14 of youngest child as the threshold for full employment conditionality considerably outside the EU or OCED norm (Murphy, 2012).

Ingold and Etherington's (2013: 630) analysis of partnered women elsewhere shows Ireland to be an outlier in the degree of labour market activation of partnered women. This is in spite of the degree to which crisis occasioned a significant increase in the number of job seekers and a parallel increase in numbers of QAs from 126,037 in 2007 to 194,190 in 2014. The numbers of dependent children in these households also increased from 120,154 to 307,463 , an overlap with the doubling of child poverty from $6 \%$ in 2007 to $12 \%$ in 2013 (Central Statistics Office (CSO), 2014). Table 3 shows a four-fold increase of QAs attached to job seekers payments (from 22,175 in 2007 to 80,029 in 2014), and an increase of QAs attached to employment support payments (from 6149 in 2007 to 17,093 in 2014). This increase can be directly attributed to the economic crisis, and can be contrasted with a pre-crisis decline in the numbers of QAs associated with working age payments (DSCFA, 1999). However, Callan et al. (2012) find job seeker households with a QA are less likely to leave the live register, suggesting numbers of QAs will decline at a slower rate than the overall job seeker count. Numbers of lone parents claiming social welfare declined from 85,084 in 2007 to 78,246 in 2013; and as a cohort now distributed across OFP, JSTA and JSA, they will be become less statistically visible. There has been no recent gender disaggregation of this QA data since Murphy (2003) found 98 per cent of QAs were women. It is likely the percentage of male QAs has risen but it is likely that, similar to the UK, over 90 per cent of QAs are still women (Millar, 2003).

Watson et al. (2012) show the macro economic crisis was associated with a phenomenal growth in jobless households, with Ireland having 23 per cent (over twice 
Table 3. Numbers of recipients of qualified adult and full child dependent allowances. ${ }^{\text {a }}$

\begin{tabular}{|c|c|c|c|c|}
\hline & 2007 & 2007 & 2014 & 2014 \\
\hline Payment category & QAs & $\begin{array}{l}\text { Children in } \\
\text { households } \\
\text { with QA payment }\end{array}$ & QAs & $\begin{array}{l}\text { Children in } \\
\text { households } \\
\text { with QA payment }\end{array}$ \\
\hline $\begin{array}{l}\text { Working age income } \\
\text { supports (incl } \\
\text { JSA and JSB) }\end{array}$ & 26,688 & 68,747 & 80,029 & 226,339 \\
\hline In-work payments & 6149 & 14,256 & 17,093 & 29,463 \\
\hline $\begin{array}{l}\text { Illness, disability } \\
\text { and caring } \\
\text { payments }\end{array}$ & 25,925 & 33,997 & 24,883 & 38,892 \\
\hline $\begin{array}{l}\text { Contributory and } \\
\text { non contributory } \\
\text { pensions }\end{array}$ & 67,275 & 3154 & 72,185 & 12,769 \\
\hline Total & 126,037 & 120,154 & 194,190 & 307,463 \\
\hline
\end{tabular}

aPaid in respect of QAs to insurance and assistance (means-tested claimants) in 2007 and 2014.

Source: compiled by author: DSFCA (2007: 18), DSP (2015: 47).

the European average) of jobless households and with children living in 53 per cent of such households. Savage et al. (2014) focus on the QA payment when they argue the structure of family based payments is a key concern of labour market policy. The QA appears a central actor in both unemployed households and in jobless households with a child or adult disability, yet remains under-analysed and under-prioritised in policy terms. Despite the reality that family-based means testing helps to perpetuate the existing gender division of paid and unpaid work (Millar, 2003: 69), there is a stubborn resistance to policy reforms that might address this pressing issue. QAs remain an invisible and largely untold story of the crisis.

\section{Giving voice to partners or QAs in Ireland}

The Irish state does not collate or report data about the labour force participation rates of QAs, ages of their children, their educational background or labour market aspirations. The previously unpublished qualitative data presented below, while small in scale and dated, is the only recent account of women QAs and is offered in the spirit of a small beginning in addressing this deficit of information and giving voice to these women. Collected in 2008, it is accurate in the sense that no significant rule changes have been made since the data was collected. However, the experience of crisis has doubtless had an impact, both in shifting attitudes to employment for both second earners and their partners and in the scale of deprivation experienced in jobless households (CSO, 2014; European Commission, 2014). Given data limits, we make no claim for generalisability 
but point to the need for substantial qualitative research and gender disaggregation of administrative data.

We proceed by outlining the views of 10 women interviewed in Summer 2008. All women interviewed were either married or cohabiting with means-tested welfare recipients and accessed through purposive sampling using snowball techniques. Interviews were conducted in an ethical manner with participants guaranteed confidentiality and data fully anonymised. These working class women from outer suburban areas of Dublin were interviewed in their own homes. Interviews were taped, transcribed and manually analysed using themes from the semistructured interview schedule as well as emergent codes. Partners of JSA households accounted for just over half of the sample, three lived with men in disability claim households and the oldest interviewee was partnered with a Pre-Retirement Allowance claimant. The vast majority of partners were in their late 30 s/early $40 \mathrm{~s}$ with the youngest women aged between 25 and 29 years and the oldest in her 60s, and most had left school with few or no qualifications. All had children ranging from between age eight to adult. One woman had only one child, but the majority had three children and the highest number of children was six, and all but one lived in local authority housing. The four interviews with policy actors were conducted in 2014 with the primary objective of understanding contemporary Irish policy regarding QAs. Analysis of this data informs the concluding section of this article. We now proceed to contextualise the experiences of Irish QAs mirroring the earlier literature review headings - 'Marital and couple homogamy and codependence', 'Care and gendered moral rationality', 'Health' and 'Financial decision-making'. We reflect emergent themes in a short section reporting 'Social welfare supports and education'.

\section{Marital and couple homogamy and codependence}

All interviewees highlighted the importance of work and demonstrated a work ethic. However attitudes towards work differed according to age, with older women holding more traditional views of gender roles and being less positive towards participation in paid employment. Reflecting on prior experiences of working, some angrily resented the burden of taking over the breadwinner role while also managing household chores and childcare: 'I was left doing everything. Coming home having to face everything just got too much for me'. Juggling the different roles left no time for their own needs. In addition, women felt old before their time and frustrated by missing out on motherhood: 'I feel like I've lived two lifetimes. I feel old. Nobody ever looks after my needs. It's always me tending to everybody else. Being left with the burden of everything, that takes its toll after a while'.

Some women felt men may not want women to work: 'You don't need to work, you're a woman', or that males could veto participation in unequal power relations: 'Sure I can hardly go to the shops without him wanting to know where I am, never mind working'. There were clear instances of couple codependence, with men over reliant on partners to relieve the domestic isolation associated with unemployment: 'Us women can go next door and have a cup of tea with friends, the men won't. 
It's the fear of being in the house on their own and they want you there with them'. Some women felt constrained by husbands' expectations: 'It suits him that I can't work. He wouldn't say I couldn't work but he wouldn't like it if I did. He'd prefer to have me here'. This codependence creates conflict: 'Because he has nothing else to do with his time, he nitpicks at every little thing. He drives me crazy and it can make you feel very on edge. It's not fair on the kids'. Experiences were mixed, with some younger husbands supporting household and caring responsibilities: 'I am lucky. His experience when he was younger was that his mother worked so he hasn't got a problem', while other (older) husbands were less accommodating: 'When you don't have any support, it's very hard, everything gets on top of you. I resented my situation'.

\section{Care and gendered moral rationality}

Caring responsibilities constituted the dominant barrier to paid employment. Showing strong gendered moral rationality, some partnered mothers' preferences for providing direct parental care took precedence over paid employment. One woman described: 'Being a mother and being a homemaker are extremely important jobs, it doesn't make sense to pay somebody to do a job that you do better or you feel you do better than them anyway', while another: 'preferred not to work, I would have preferred to be with my kids and not leaving them in the evenings but I had no choice'. Issues of trust were also raised: 'Nobody minds your children like you do. You just don't know what happens when you're not there, because they're not old enough to tell you'. Leaving older children at home unattended in a disadvantaged area was also a concern: 'You need to be there to keep them on the straight and narrow especially in the areas we're living in, like we're not living in ...' There were ambivalent feelings about leaving men in a caring role, ranging from being defensive about men to 'it's humiliating for men to take over the caring role' - 'men are simply not trained to look after children', to comments about men's lack of input into care: 'He didn't want to know, he wouldn't mind them for me if I had of went out to work. Well I wouldn't have left him with the kids anyway'. Family support was important: 'He didn't mind me working because he wasn't left with the kids. It was me ma, me ma would take them. If I hadn't had me mother, I wouldn't be able to do it'.

\section{Health}

The relationship between health, stress and poverty was clear. One woman described how she 'had to go see the doctor because I couldn't cope with it all . . I couldn't stop crying and she put me on anti-depressants ... I do feel guilty'. Care considerations associated with ill health also featured. As Coleman and Seeds (2007) found, care requires significant time and energy, restricting time for employment. Similar to findings in international literature, stress-related illness associated with pressures of coping and managing financially presented significant barriers to accessing and maintaining employment: 'It's very hard for me. He has become more and more depressed over the years and finds it difficult. He wouldn't be able to mind the kids 
because he has good days and bad days'. A woman who had left work due to healthrelated issues described how 'He was quite happy for me to work and when I had to leave he made me feel like a failure'. One woman in her 40s had worked for 16 years when the difficulty of juggling being a wife, mother and breadwinner meant her health started to deteriorate: 'It takes your confidence. I had a lot going on, I became a little nervy, and I needed time out of work because I was mentally exhausted. I couldn't sleep and when I did, I'd wake up and couldn't get back to sleep again, me head just wouldn't switch off'. Most of the women spoke about the difficulty of living on a low income and the impact this had on family life: 'I had to leave work. I was working full-time but lost a stone in weight not being able to cope. The expense of living and the stress of living on low wages and then you're trying to get to work and you're stuck in traffic, then come home, do the housework and get the dinner on the table. It just wasn't worth it'. Addiction was also a barrier. One couple were chronic alcoholics, another husband was a heavy drinker whose wife would not leave the children in his care: 'I wouldn't go out and leave the kids with him because of his drinking. I wouldn't have left them because he was always drinking'. One woman in employment was reluctant to discuss her health problems with (male) employers: 'I hated men at that time because I was going through a bad stage and the last thing I wanted to do was sit and tell a man my business'. Employers were not perceived to be family-friendly or understanding, and the absence of familyfriendly policies in the workplace leaves little scope for sick leave or caring for a sick relative: 'When me Da got cancer and was having all the tests, I was hauled into the office. I had to get a letter from the Mater stating that me Da was in hospital'.

\section{Financial decision making}

Daly and Leonard (2002) found that two-parent households were less informed than lone parents on a range of different issues. Earnings interacting with the male's social welfare payment restricted women to working a limited number of hours: 'I couldn't have worked full-time because if I had of worked full-time, he would of lost his labour. He would of lost about $€ 200$ a week so therefore I wouldn't go full-time'. There is pressure and strain on a couple's relationship when tight finances require negotiation - most interviewees mentioned the expense of household bills and the constant fear of falling behind. Managing poverty was a central feature and fell on women's shoulders: 'When he gets his dole, he gives it to me and when money is needed for petrol, I give him what he needs'. The burden of responsibility left women highly stressed trying to make ends meet: 'Sometimes I just can't cope. I fell behind in the rent so I went to Citizen's Advice. I broke down in front of her. I told her I couldn't take it anymore, him and the kids and not having any money'. Another woman resented the financial responsibility of work and stated: 'I despise him for having to cope with it all. Our relationship is gone. The stress I've endured has hindered our relationship. There's nothing left between us. I've been through the mill and back. I had nobody to talk or turn to'. Children's welfare figured very prominently in the decision-making process: 'It would have to be a job that actually 
pays me enough money to go out and actually leave my children. So many people are stuck in a position that it does not pay to go out to work'. Women were clearly constrained: 'I'd go to work tomorrow. I'd be gone, gone out the door, when you've good provisions around you that is. I wouldn't take a job without sitting down deliberating whether the money is right'. Some were fully aware of the poverty traps and generally felt they'd be no better off when participation costs were taken into consideration. The restriction to local employment with flexible hours constrained their ability to combine employment and family responsibilities.

\section{Social welfare supports and education}

While aware of the overall impact of earnings on social welfare payments, women were often unsure about the specific impact their employment would have on the main claimant's payment, or on how signing for credits could protect future entitlement. Information around entitlements was not readily accessible and had to be sought out. As in the UK experience, dealing with social welfare officers was often viewed negatively, with many criticising the attitudes of staff: 'I was trying to explain our situation. I was trying to tell her that me husband suffers with depression and she was sitting there ignoring me through the glass'. Women generally felt that people not living on benefits don't truly understand and found staff quite dismissive: 'We had a terrible experience with the social welfare. Unless people are living on benefits, they don't really understand'. Others felt they were viewed by staff with suspicion and were made to feel like spongers. One woman recounted a very stressful and humiliating experience of bringing her husband along to ask for financial assistance: 'She was like, oh no, I couldn't pay that. I could see he was getting annoyed and just wanted to get out. When we got outside, I had to listen to him for bringing him there in the first place'.

Women also made a clear differentiation between investing long term in education and more short-term decisions about paid employment. Older women mentioned leaving school early in order to supplement the family income. Some left because of teenage pregnancy. Three of the women interviewed had gone on in later life to participate in further education with one in the process of completing a degree. One woman swapped eligibility with her spouse to avail of back to education supports. Another stressed the supportive role her husband played: 'My husband and I nearly did the degree together'. All recognised the importance of education and viewed it as crucial to achieving meaningful work. A desire to improve their situation and better themselves was the main driving force when deciding to return to education. Instilling a work ethic in children was also seen as an important reason for education and training: 'I want my children to see me going out. I needed to do something to show the kids you have to keep on trying to make an effort'. Women highlighted how a return to education helped build confidence and reclaim identity, but that husbands could feel threatened: "you start getting your own ideas and thoughts... your husband sees that change and they think you're going to develop away from them'. Keeping children in education was also a theme. One woman described how financial strain and the stress of combining care and work 
impacted negatively on her relationships with her husband and children, one consequence being that her children did not want to attend school.

\section{Discussion}

What can we learn from these stark accounts of partners and how should Irish policy respond to their pressing accounts of poverty, stress, unequal care loads and illhealth and to their aspirations for better quality lives? These Irish qualitative findings are broadly consistent with the international literature. Interviews took place at the end of the Celtic Tiger and the beginning of the recent economic crisis. Even then the reality and extent of poverty, stress and hardship is striking and distressing. Poverty, deprivation and related ill-health and mental distress have deepened over the recent economic crisis (CSO, 2014) and contemporary policy needs to factor in the material impact of such stress on health and capacity to cope. Also striking, and consistent with some UK literature (Aston et al., 2007; Bennett, 2002; Bewley et al., 2005), is the exposition of a strong patriarchal undertone in partners' lives. Like Daly and Kelly (2015), we see the significance of family in a context of poverty and lowincome. We also see deeply gendered care patterns and experiences and significant domestic power and control dynamics (more dominant in the older cohort). There is a clear pattern of codependence where adult relationships, household pressures, care responsibilities and lack of local services are crucial factors mediating decisions to work, a pattern also seen in qualitative research in local UK labour markets in the same period (Yeandle, 2006). Policy needs to consider how the management of care, poverty and ill health are experienced by cohabiting couples. Financial concerns and the role of the partner are of significant importance and mental health-related issues are linked to the difficulties of managing a low income.

A strong, gendered care-ethic mediated narratives of work, and decisions around labour market participation were closely related to age and number of children. Those with dependent children expressed a desire to take up work in the future when their children were older, and clearly valued education and training. While formal care was not given much significance, the importance and ability to draw on informal care arrangements is important. Care is no less an issue in twoparent families. The women stressed how difficult it is to manage care when neither the home or work environment is supportive of the range of care-work women undertake in the family. The domestic transition from carer to worker is difficult, fraught, often unsupported and sometimes impossible, especially when employment is low-paid, of poor quality and inflexible.

We see the tensions and ambiguities in how current policy impacts on partners. Policy in Ireland (as elsewhere) is ambiguous. At one level it continues to facilitate 'wifely labour', the system of QA earned income disregards also incentivises and facilitates a pattern of very flexible part-time and low-paid work in gender-segmented labour markets particularly populated by working class women. We see a 'modified wifely labour' where domestic care and work is often combined with part-time work and where participation in paid employment is mediated by the difficulty of 
combining decent work with positive parenting or care roles. This is consistent with Coleman and Seed's (2007) conclusion that constraints and availability of decent work rather than attitudes restricted work. These women value labour market attachment (past, present and future), and need active support, information and encouragement to maximise their potential but critique the quality and quantity of information about job opportunities and the lack of local, family-friendly employment. This echoes recommendations elsewhere, for staff training, information and personal supports for women making this transition (Bewley et al., 2005).

\section{Conclusion}

Both claimants and partners live in low-employment-intensity households. These experience a high risk of adult and child poverty, poor education and social exclusion. While a logical priority for policy, little is known statistically or sociologically, about partners in these households. Consistent with international literature, this analysis suggests that the experiences of Irish partners, while heterogeneous, overlap with but are qualitatively different from those of lone parents. More research about partners is needed to inform policy. Irish society is not static. More women are working and want to work (Readdick et al., 2012; Redmond et al., 2010). Women who previously worked and lost employment have different attitudes and cultural expectations about labour market participation (Murphy, 2012). These interviews largely reflect pre-economic crisis Ireland. The increase in the numbers of QAs during the recent economic crisis likely reflects a more gender-diverse and younger group, but current data limitations mean we can only speculate.

What can be said of the Irish government's policy trajectory for partners? Irish public policy, through family-based taxation transfers and unconditional QAs, actively supports the choice of one parent in a coupled household to provide care full-time in the home while now explicitly denying other (lone) parents this 'choice'. The intention is not to invite 'divisive and invidious comparisons' between the two groups but to draw attention to ongoing 'the lack of strategic response' to the need for reform (McCashin 1997: 4). Why, compared to other Anglo Saxon states and given the significant growth in numbers of QAs over the recent economic crisis, has Irish policy ignored this group while disproportionately focusing on lone parents? Interviews with key policy actors in statutory and lobbying organisations and analysis of recent policy designs, policy consultations and parliamentary debate confirms the policy agenda for partners is considered a medium to long term rather than an immediate priority (Higgins, 2014; McKeon, 2015). The male breadwinner activation model will continue (Rice, 2015), with some shift in the new Irish activation strategy Pathways to Work 2016-2020. This, in the context of recovery and growth, commits to expand activation to non-employed working age people beyond registered unemployed. It will encourage expanded labour market participation "by means of supportive services or increased conditionality or both" (DSP 2016: 14). QAs or partners (along with lone parents, people with disabilities and carers) are identified as a possible priority for expansion and future policy initiatives might 
include use of the JST mechanism, promotion of registration of QA's in their own right, and recognition of time spent as lone parent or qualified adult in the determining eligibility for labour market supports (DSP 2016: 22).

There are tensions and ambiguities in all reform agendas (Daly, 2011). However, a number of factors might account for this long-fingering of the issue. Politically the issue is sensitive. There is a fear of awakening a sizeable 'women in the home' lobby that successfully campaigned in 2002 to stall further tax individualisation. The political impulse is to avoid an anticipated backlash and 'to leave well alone'. Earlier UK debates are repeated, with arguments against imposing work requirements on older women with little employment experience, or on women with children (Millar, 2003: 70). Some values portrayed in the 10 interviews are consistent with values enshrined in the 1937 Irish Constitution that promotes and celebrates 'women's role in the home' and their dependent status (Crowley, 2015). The gender and age composition of policy makers and politicians means that, as sons and husbands, they are likely to have benefited from the patriarchal dividend offered by 'wifely labour'. As McCashin (1997: 5) observed two decades ago, there is strong resistance to arguments for change.

Resource and capacity implications arise in moves towards individualisation. Granting upwards of 150,000 working-age partners an individual right to payment, while leaving the family means-test untouched, does not necessarily have significant budget implications, but would impact on an under-resourced and already overcapacity social security and public employment administrative system, as well as placing more demand on stretched training and education services. A more ambitious individualisation of social protection rights which partially individualises the means-test would have significant resource implications. A government attempting to gain electoral dividends from decreasing unemployment is also likely to resist policy measures that would lead to increased numbers seeking JSA.

Individualisation might also imply conditionalities and, as was recently clarified to a parliamentary committee, 'brings with it both the responsibilities and rights, in terms of employment services and programmes that attach to job-seekers payments' (McKeon, 2015: 3). In practice, the level of conditionality imposed is a political choice. It is unclear how conditionality can or should be managed for couples with care obligations. Ideally, policy should promote shared care and paid employment and so share easements of conditionality. Those most likely to seek reform or individualisation of the QA from the perspective of gender equality fear that calls for reform, individualisation or modernisation may hasten a similar conditionality or sanctions-driven reform agenda as that being experienced by lone parents in Ireland and by partners internationally. Jaehrling et al. (2014) and Keck and Saraceno (2013) argue that activating partners into low-paid part-time work fails to achieve positive outcomes for women or children. Up to 100,000 Irish partners already utilise income disregards to work part-time as flexible workers in low-paid, casual employment in catering, hospitality, health care and tourism and retail industries. The pattern of work is only made sustainable by the degree to which the income disregard acts as an employer subsidy or form of corporate welfare. Conditionality would reinforce this pattern. 
UK policy is often a policy transfer model for Ireland (Murphy, 2012). In the UK regime both partners (with or without children) must individually fulfil work search eligibility conditions, but the family means-test is retained and the benefit is not individually paid (Millar, 2003: 71). A more ambitious alternative is found in the Australian partial individualisation model where a conditional but more individualised means-test facilitates an individualised payment for partners of unemployed or those in low-paid work but excludes those with moderate or high earning partners from accessing welfare payments. Ironically, it was this Australian model which inspired the original DSFA 2006 proposals for Irish reform. These proposals were never universally popular and were quickly abandoned under cover of the recent economic crisis. However, it may well be time to revisit them.

\section{Acknowledgements}

I would like to thank Marion Cregan for research assistance in 2008.

\section{Declaration of conflicting interests}

The author(s) declared no potential conflicts of interest with respect to the research, authorship, and/or publication of this article.

\section{Funding}

The author(s) disclosed receipt of the following financial support for the research, authorship, and/or publication of this article: This work was supported by Maynooth University's SPUR (Summer Programme for Undergraduate Researchers) programme.

\section{References}

Arrowsmith J (2004) A Review of What We Know About Partners of Benefit Recipients. Report. Leeds: Department for Work and Pensions.

Aston J, Hooker H, Page R, et al. (2007) Pakistani and Bangladeshi Women's Attitudes to Work and Family. Report No. 458. Leeds: Department for Work and Pensions.

Bennett F (2002) Gender implications of current social security welfare reforms. Fiscal Studies 23(4): 559-584.

Bewley H, Dorsett R and Thomas A (2005) Joint Claims for JSA Evaluation - Synthesis of Findings. Report No. 23. Leeds: Department for Work and Pensions.

Bonjour D and Dorsett R (2002) New Deal for Partners: Characteristics and Labour Market Transitions for Eligible Couples. Report No 134. Leeds: Department for Work and Pensions.

Callan T, Keane C, Savage M, et al. (2012) Work incentives: New evidence for ireland. Budget Perspectives 2013. Dublin: ESRI.

Carlile C, Fuery M, Heyworth C, et al. (2002) Welfare Reform Pilots: Characteristics and Participation Patterns of Three Disadvantaged Groups. Occasional Paper No. 5. Canberra: Department of Family and Community Services.

Central Statistics Office (2014) Survey of Living and Income Conditions 2013 Dublin: CSO. Civic Forum (2015) Civic Forum on One Parent Families. Briefing document, 15 April. Dublin: Seanad Éireann. 
Coleman N and Seeds K (2007) Work Focused Interviews for Partners and Enhanced New Deal for Partners Evaluation: Synthesis of Findings. Report No. 417. Leeds: Department of Work and Pensions.

Collard S and Atkinson A (2009) Making Decisions about Work in One-Earner Couples Pensions Research. Report No 560. Leeds: Department for Work and Pensions.

Crowley L (2015) Shifting concept of family law in Ireland. What of Article 41.2: UCC Annual Law Lecture, Article 41.2.1. University College Cork, 3 November.

Daly M (2011) What adult worker model? A critical look at recent social policy reform in Europe from a gender and family perspective. Social Politics 18(1): 1-23.

Daly M and Kelly G (2015) Families and Poverty: Everyday Life on a Low Income. Bristol: Policy Press.

Daly M and Klammer U (2005) Women's participation in European labour markets. In: Gerhard U, et al. (eds) Working Mothers in Europe: A Comparison of Policies and Practices. Cheltenham: Edward Elgar, pp. 122-143.

Daly M and Leonard M (2002) Against All Odds, Family Life on a Low Income in Ireland. Dublin: Institute of Public Administration.

Department of Social, Community and Family Affairs (DSCFA) (1996) Expert Working Group on Tax/Social Welfare Integration. Report. Dublin: DSCFA.

Department of Social, Community and Family Affairs (DSCFA) (1999) The Report of the Working Group Examining the Treatment of Married, Co-habiting and One-Parent Families under the Tax and Social Welfare Codes. Report. Dublin: DSCFA.

Department of Social, Community and Family Affairs (DSCFA) (2000) Report of Working Group on Women's Access to the Labour Market. Report. Dublin: DSCFA.

Department of Social and Family Affairs (DSFA) (2006) Government Discussion Paper: Proposals for Supporting Lone Parents. Report. Dublin: DSFA.

Department of Social and Family Affairs (DSFA) (2007) Annual Statistical Report 2007. Dublin: DSFA.

Department of Social Protection (DSP) (2010) Report on the Desirability and Feasibility of Introducing a Single Social Assistance Payment for People of Working Age. Report. Dublin: DSP.

Department of Social Protection (DSP) (2015) Annual Statistical Report 2014. Dublin: DSP. DSP (2016) Pathways to Work 2016-2020. Dublin: DSP.

Duncan S and Irwin S (2004) The social patterning of values and rationalities: Mothers' choices in combining caring and employment. Social Policy and Society 3(4): 391-399.

European Commission (2014) Coping with the Crisis, Eurobarometer Aggregate Report. Brussels: European Commission.

Gazso A (2007) Balancing expectations for employability and family responsibilities while on social assistance: Low income mothers' experiences in three Canadian provinces. Family Relations 56(5): 456-466.

Higgins AM (2014) NWCI Submission to Joint Oireacthas Committee on Education and Social Protection, 14 June.

Ingold J (2010) Policy responses to partnered women outside the labour market. What can Britain learn from Australia and Denmark? PhD thesis, University of Sheffield, UK.

Ingold J and Etherington H (2013) Work, welfare and gender inequalities: An analysis of activation strategies for partnered women in the UK, Australia and Denmark. Work, Employment and Society 27(4): 621-638. 
Jaehrling K, Thorsten K and Mesaros L (2014) A paradox of activation strategies: Why increasing labour market participation among single mothers failed to bring down poverty rates. Social Politics 22(3): 86-110.

Kasparova D, Marsh D, Vegeris S, et al. (2003) Families and Children Study, Work and Childcare. Report No. 191. Leeds: Department of Work and Pensions.

Keck W and Saraceno C (2013) The impact of different social-policy frameworks on social inequalites among women in the European Union: The labour market particpation of mothers. Social Politics 20(3): 297-328.

King A, Bradbury B and McHugh M (1995) Why Do the Wives of Unemployed Men Have Such Low Employment Rates? Report No. 125. Sydney: SPRC University of New South Wales.

Kopf E and Zabel C (2014) Active Labour Market Programmes for Women with a Partner: Challenge or Replication of Traditional Gender Roles? IAB Paper, No. 6/2014. Nuremburg: Institute for Employment Research.

Kornstein SG and Wojcik BA (2002) Depression. In: Kornstein SG and Clayton AH (eds) Women's Mental Health: A Comprehensive Book. New York: The Guilford Press.

Korpi W, Ferrarini T and Englund S (2013) Women's opportunities under different family policy constellations: Gender, class, and inequality trade-offs in western countries re-examined. Social Politics 20(1): 1-40.

Leschke J and Jepsen M (2014) Is the economic crisis challenging the prevailing gender regime? A comparison of Denmark, Germany, Slovakia, and the United Kingdom. Social Politics 21(2): 485-508.

Lietzmann T (2014) After recent policy reforms in Germany: Probability and determinants of labour market integration of lone mothers and mothers with a partner who receive welfare benefits. Social Politics 21(4): 585-616.

McCashin A (1997) The tax and welfare treatment of households. In: Ireland (1999) The Report of the Working Group Examining the Treatment of Married, Cohabiting and OneParent Families under the Tax and Social Welfare Codes. Appendix 2 Report. Dublin: Government Publications Office, pp. 1-13.

McCashin A (2004) Social Security in Ireland. Dublin: Gill and Macmillan.

McKeon J (2015) Department of Social Protection Submission to Joint Oireacthas Committee on Education and Social Protection. 14 October.

McLeavy J (2007) Engendering New Labour's workfarist regime: Exploring the intersection of welfare state restructuring and labour market policies in the UK. Gender, Place and Culture: A Journal of Feminist Geography 14(6): 721-743.

McQuaid R, Graham R, Shapria, M, et al. (2013) Economic Inactivity Strategy Literature Review Project. Report. Edinburgh: Employment Research Institute, Napier University.

McRae S (2003) Constraints and choices in mothers' employment careers: A consideration of Hakim's Preference. British Journal of Sociology 54(3): 317-338.

Millar J (2003) Squaring the circle? Means testing and individualisation in the UK and Australia. Social Policy and Society 3(1): 67-74.

Millar M, Coen L, Rau H, et al. (2007) Towards a Better Future: Research on Labour Market Needs and Social Exclusion of One-Parent Families in Galway City and County. Galway: Galway City Partnership.

Murphy MP (2003) A Woman's Model for Social Welfare Reform. Dublin: National Women's Council of Ireland. 
Murphy MP (2008) Reframing the Irish Activation Debate: Accommodating Care and Safeguarding Social Rights and Choices. The Policy Institute, Blue Paper Series No 23. Dublin: TCD.

Murphy MP (2012) From Careless to Careful Activation: Making Activation Work for Women. Dublin: NWCI.

Murphy MP (2014) Ireland's lone parents, social welfare and recession. The Irish Community Development Law Journal 3(2): 6-21.

NWCI (2006) NWCI presentation to DSFA consultation on DSFA proposals for supporting lone parents, Dublin: Farmleigh House, 27 April.

O'Connor O and Murphy MP (2008) Gender and the Irish social welfare system. In: Barry $\mathrm{U}$ (ed.) Where Are We Now? New Feminist Perspectives on Women in Contemporary Ireland. Dublin: TASC, pp. 30-52.

One Family (2008) Lone Parents and Employment: What are the Real Issues? Dublin: One Family.

Readdick C, Farrell AP and Koepke LA (2012) Irish voices: Families in a globalizing economy. Journal of Family Issues 33(3): 1-10.

Redmond J, Valiulis M and Drew E (2010) Literature Review of Issues Related to Work-Life Balance, Workplace Culture and Maternity/Childcare Issues. Dublin: Crisis Pregnancy Agency.

Renda J (2007) Employment Aspirations of Non-Working Mothers with Long-Term Health Problems. Research Paper No. 40. Canberra: Australian Institute of Family Studies.

Rice D (2015) Applying welfare regimes in empirical analysis: The example of activation. Social Policy Review 27: 171-198.

Russell H, Smyth E, Lyons M, et al. (2002) Getting Out of the House: Women Returning to Employment, Education and Training. Dublin: Liffey Press.

Sainsbury D (1999) Gender and Welfare State Regimes. Oxford: Oxford University Press.

Savage M, Callan T, Keane C, et al. (2014) Welfare Targeting and Work Incentives. Dublin: ESRI.

Schober P and Scott J (2012) Maternal employment and gender role attitudes: Dissonance among British men and women in the transition to parenthood. Work, Employment and Society 26(3): 514-530.

Shaver S and Bradshaw J (1995) The recognition of wifely labour by welfare states. Social Policy and Administration 29(1): 10-25.

Singley S (2003) Barriers to Employment among Long-term Beneficiaries: A Review of Recent International Evidence. Working Paper 04/04. Auckland: CSRE.

Singley S and Callister P (2004) Polarisation of Employment, 1986-2002: New Zealand in the International Context. Working Paper 06/04. Auckland: CSRE.

Stone V, Hulusi A, Tovey P, et al. (2000) Evaluation of the New Deal for Partners of Unemployed People: Pathfinders. Sheffield: Employment Service.

Watson D, Maître B and Whelan CT (2012) Work and Poverty. Dublin: ESRI.

Women's Aid (2014) Women's Aid - input into FLAC Shadow Report under the International Covenant on Economic, Social and Cultural Rights May 2014. Dublin: Women's Aid. Available at: http://www.womensaid.ie/policy/publications/womens-aid-input-to-flacicescr-shadow-report-may-2014/.

Yeandle S (2006) Director's Final Report: The Gender and Employment in Local Labour Markets Research Programme. Centre for Social Inclusion, Sheffield Hallam University. 